\title{
KERATINOLYTIC BACTERIA ISOLATED FROM FEATHER WASTE
}

\author{
Alessandro Riffel; Adriano Brandelli* \\ Laboratório de Bioquímica e Microbiologia Aplicada, Departamento de Ciência de Alimentos, ICTA, Universidade Federal do \\ Rio Grande do Sul, Porto Alegre, Brasil
}

Submitted: December 16, 2004; Approved: July 13, 2006

\begin{abstract}
The aim of this study was to characterize keratinolytic bacteria isolated from feather waste. Four isolates were selected after growth on solid medium with feather meal as sole carbon and nitrogen source and screened for proteolytic activity on milk agar plates. Three isolates were Gram-negative (belonged to the genera Burkholderia, Chryseobacterium and Pseudomonas) and one was Gram-positive (Microbacterium sp.). These bacteria grew on diverse keratin wastes such as feather meal, raw feathers, chicken nails, hair and wool. Keratinase activity was detected during growth, but the complete degradation of these substrates was not always achieved. The proteolytic character of crude enzymes was assessed using azokeratin and azocasein as substrates. The keratinases were active on both substrates and were similar in keratin hydrolysis when compared with commercially available microbial peptidases. These novel keratinolytic isolates have potential biotechnological use in processes involving keratin hydrolysis.
\end{abstract}

Key words: feather, keratin, peptidase, proteolysis

\section{INTRODUCTION}

Feathers are produced in large amounts as a waste byproduct of poultry processing plant. A current value-added use for feathers is the conversion to feather meal, a digestible dietary protein for animal feed, using physical and chemical treatments. These methods can destroy certain amino acids and decrease protein quality and digestibility $(18,26)$.

The nutritional inferiority and insolubility of native feather protein derive from the composition and molecular configuration of constituent amino acids that ensure the structural rigidity of feathers (22). Resistance to proteolytic enzymes has been attributed to the complex structure of $\beta$-keratin filaments. In addition, disulfide cross-links produce a compact threedimensional network (3), as a result of intermolecular disulfide bonds between rod domains and terminal domains of the constituent molecules (22).

The nutritional upgrading of feather meal through microbial or enzymatic treatment has been described. Feather meal fermented with Streptomyces fradiae and supplemented with methionine resulted in a growth rate of broilers comparable with those fed isolated soybean protein (5). The use of feather-lysate from Bacillus licheniformis with amino acid supplementation produced a similar growth rate in chickens when compared to chickens fed with a diet that included soybean meal (28). The crude keratinase enzyme produced by $B$. licheniformis significantly increased the total amino acid digestibility of raw feathers and commercial feather meal (12). This enzyme increased the digestibility of commercial feather meal and could replace as much as $7 \%$ of the dietary protein for growing chicks (20).

Keratinolytic microorganisms and their enzymes may be used to enhance the digestibility of feather keratin. They may have important applications in processing keratin-containing wastes from poultry and leather industries through the development of non-polluting methods (21). A number of keratinolytic microorganisms have been reported, including some species of Bacillus (1,27), actinomycetes (2,29) and fungi $(11,25)$. Generally, an increase in keratinolytic activity is associated with thermophilic organisms, which require high energy inputs to achieve maximum growth and the

*Corresponding Author. Mailing address: ICTA-UFRGS, Av. Bento Gonçalves, 9500. 91501-970, Porto Alegre, RS, Brasil. Fax: (+5551) 3316-7048. E-mail: abrand@ufrgs.br 
decomposition of keratin wastes $(6,19)$. Recently, featherdegrading activity was also observed in studies of Gramnegative bacteria $(23,24)$. These bacteria can degrade raw feathers at mesophilic temperatures, and are therefore useful to develop efficient processes involving keratin substrates.

In this report, we describe the selection and characterization of mesophilic microorganisms showing keratinolytic activity isolated from a poultry processing plant at Porto Alegre, Brazil. Some properties of their keratinases were also determined.

\section{MATERIALS AND METHODS}

\section{Microorganisms}

Bacterial strains designated as $\mathrm{kr} 7$ to $\mathrm{kr} 14$ were isolated from feather waste as described elsewhere $(23,24)$. A previously characterized Chryseobacterium sp. strain kr6 that presented keratinolytic activity (23) was used for comparison. Bacterial identification was based on colony morphology, microscopic examination of Gram-stained cells, and biochemical tests $(7,16)$, comparing the data with standard species. Additionally, an API 20 E kit was used and the data was analyzed by automated interpretation with the APILAB Plus software (Bio-Mérieux, Marcy-l'Étoile, France).

\section{Effect of temperature on growth and proteolytic activity}

Milk agar plates $\left(5 \mathrm{~g} \mathrm{~L}^{-1}\right.$ peptone, $3 \mathrm{~g} \mathrm{~L}^{-1}$ yeast extract, 100 $\mathrm{mL} \mathrm{L}^{-1}$ sterile UHT non-fat milk, and $12 \mathrm{~g} \mathrm{~L}^{-1}$ agar) were prepared for primary screening of proteolytic activity. Bacteria were inoculated onto plates and incubated at $22,30,37,46$, and $55^{\circ} \mathrm{C}$ for $24 \mathrm{~h}$. Strains that produced clearing zones in this medium were selected.

\section{Enzyme assay}

Keratinase activity was assayed with azokeratin as substrate (24). The reaction mixture contained $100 \mathrm{~mL}$ of enzyme preparation and $500 \mathrm{~mL}$ of $10 \mathrm{~g} \mathrm{~L}^{-1}$ azokeratin in $50 \mathrm{mM}$ tris buffer, $\mathrm{pH}$ 8. The mixture was incubated at $45^{\circ} \mathrm{C}$ for $15 \mathrm{~min}$ and the reaction was the stopped by the addition of trichloroacetic acid to a final concentration of $60 \mathrm{~g} \mathrm{~L}^{-1}$. After centrifugation at $10,000 \mathrm{~g}$ for $5 \mathrm{~min}$ the absorbance of the supernatant fluid was determined at $440 \mathrm{~nm}$. One unit of enzyme activity was the amount of enzyme that caused a change of absorbance of 0.01 at $440 \mathrm{~nm}$ for $15 \mathrm{~min}$ at $45^{\circ} \mathrm{C}$. A similar protocol was used to determine enzyme activity on azocasein (Sigma, St. Louis, USA). Azokeratin was synthesized based on the methodology described for azoalbumin (23).

\section{Degradation of keratin wastes}

The capacity of degradation of keratin substrates was tested on medium containing $0.5 \mathrm{~g} \mathrm{~L}^{-1} \mathrm{NaCl}, 0.3 \mathrm{~g} \mathrm{~L}^{-1} \mathrm{~K}_{2} \mathrm{HPO}_{4}, 0.4 \mathrm{~g} \mathrm{~L}^{-1}$ $\mathrm{KH}_{2} \mathrm{PO}_{4}$ and $10 \mathrm{~g} \mathrm{~L}^{-1}$ of either feather meal, raw feathers, bovine hair, human hair, wool, or chicken nails powder. Degradation of substrates was visually inspected and aliquots were removed for keratinase activity assay.

\section{Enzyme production}

The organisms were cultivated in feather meal broth $\left(10 \mathrm{~g} \mathrm{~L}^{-1}\right.$ feather meal, $0.5 \mathrm{~g} \mathrm{~L}^{-1} \mathrm{NaCl}, 0.3 \mathrm{~g} \mathrm{~L}^{-1} \mathrm{~K}_{2} \mathrm{HPO}_{4}, 0.4 \mathrm{~g} \mathrm{~L}^{-1} \mathrm{KH}_{2} \mathrm{PO}_{4}$ ) for up to 8 days at $30^{\circ} \mathrm{C}$. Enzymes were obtained by centrifugation at 10,000 g for $5 \mathrm{~min}$, and culture supernatants were used as crude enzyme extracts. Keratinase activity was assayed at different cultivation times.

\section{Comparison with commercial enzymes}

Commercial enzymes (pronase E, papain and trypsin form Sigma-Aldrich, St. Louis; alcalase from Novo Nordisk, Denmark) were dissolved at $1 \mathrm{mg} \mathrm{mL}^{-1}$ in $50 \mathrm{mM}$ tris $\mathrm{pH} 7.5$ and then assayed for azoproteins as described previously.

\section{RESULTS}

\section{Characterization of keratinolytic strains}

Eight isolates were able to grow on medium containing feather meal as sole carbon and nitrogen source. The strains $\mathrm{kr} 8, \mathrm{kr} 9, \mathrm{kr} 10$, and $\mathrm{kr} 14$ produced clearing zones when tested for proteolytic activity on milk agar (Fig. 1). The largest clearing zones were observed for isolate $\mathrm{kr} 10$, with a zone diameter similar to the keratinolytic strain Chryseobacterium sp. kr6. Milk agar plates were incubated at several temperatures, and the results are summarized in Table 1 . After $24 \mathrm{~h}, \mathrm{kr} 8$ was able to grow from 22 to $46^{\circ} \mathrm{C}$ and peptidase production occurred between 22 and

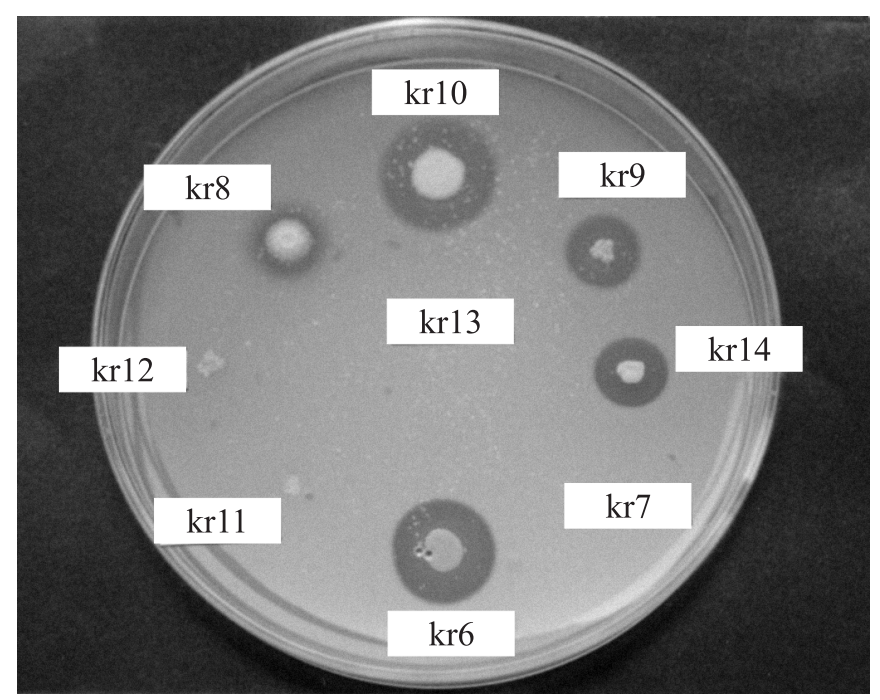

Figure 1. Production of clearing zones in milk agar plates by keratinolytic bacteria. Microorganisms were inoculated by stick and plates were incubated at $30^{\circ} \mathrm{C}$ for $24 \mathrm{~h}$. 
Table 1. Effect of temperature on growth an proteolytic activity of bacteria isolated from a poultry industry. ${ }^{\mathrm{a}}$

\begin{tabular}{cccccc}
\hline Isolate & $22^{\circ} \mathrm{C}$ & $30^{\circ} \mathrm{C}$ & $37^{\circ} \mathrm{C}$ & $46^{\circ} \mathrm{C}$ & $55^{\circ} \mathrm{C}$ \\
\hline $\mathrm{kr} 6$ & 1 & 5 & 5 & + & - \\
$\mathrm{kr} 7$ & - & + & - & - & - \\
$\mathrm{kr} 8$ & 1 & 2 & 4 & + & - \\
$\mathrm{kr} 9$ & + & 4 & - & - & - \\
$\mathrm{kr10}$ & 3 & 4 & 5 & 3 & + \\
$\mathrm{kr11}$ & + & + & - & - & - \\
$\mathrm{kr12}$ & + & + & - & - & - \\
$\mathrm{kr13}$ & - & + & - & - & - \\
$\mathrm{kr14}$ & + & 4 & 4 & - & - \\
\hline
\end{tabular}

${ }^{a}$ Proteolytic activity was estimated by the distance $(\mathrm{mm})$ between haloes and colonies after 24h. (+) Growth but not clearing zones were observed. (-) No growth or clearing zones were observed.

$37^{\circ} \mathrm{C}$. The isolate $\mathrm{kr} 10$ was able to grow form 22 to $55^{\circ} \mathrm{C}$, but produced proteolytic activity between 22 and $46^{\circ} \mathrm{C}$. The strain kr14 grew between 22 and $37^{\circ} \mathrm{C}$ and produced proteolytic activity between 30 and $37^{\circ} \mathrm{C}$. The other isolates exhibited inferior results in growth and proteolytic activity.

The identification of the keratinolytic bacteria was based on cell morphology, colony morphology, and several biochemical tests. Isolates $\mathrm{kr} 8, \mathrm{kr} 9$ and $\mathrm{kr} 14$ were determined to be Gramnegative coccobacilli by microscopic observation, whereas isolate $\mathrm{kr} 10$ was determined to be a Gram-positive rod. The isolate kr14 formed golden-yellow colonies on feather meal agar plates. Together with the results of physiological tests and API $20 \mathrm{E}$, the characteristics indicated that $\mathrm{kr} 8$ is a Bulkholderia sp., kr9 is a Chryseobacterium sp., and kr14 is a Pseudomonas sp. The strain kr10 is a Microbacterium sp.

\section{Hydrolysis of keratin wastes}

The strains were tested for their capacity to degrade diverse keratin wastes. Cultivation on all substrates resulted in the production of keratinase, although maximum values were obtained on feather meal and feathers (Fig. 2). Strains kr6 and kr10 degraded chicken feathers completely. The strain kr14 disintegrated feather barbules but not all rachises. Minor feather degradation was achieved by strains $\mathrm{kr} 8$ and $\mathrm{kr} 9$. Although keratinase activity was detected during growth on the different substrates, no important degradation of wool or hair was consistently observed (data not shown).

\section{Keratinolytic activity}

Keratinolytic activity of the isolates was monitored during growth in feather meal broth. The keratinolytic activity of isolates $\mathrm{kr} 6$ and $\mathrm{kr} 10$ increased in the first days, while other isolates showed a maximum keratinase activity later (Fig. 3).
The highest keratinolytic activity was consistently observed from isolate $\mathrm{kr} 6$. An increase in $\mathrm{pH}$ was always observed during growth on feather meal broth.

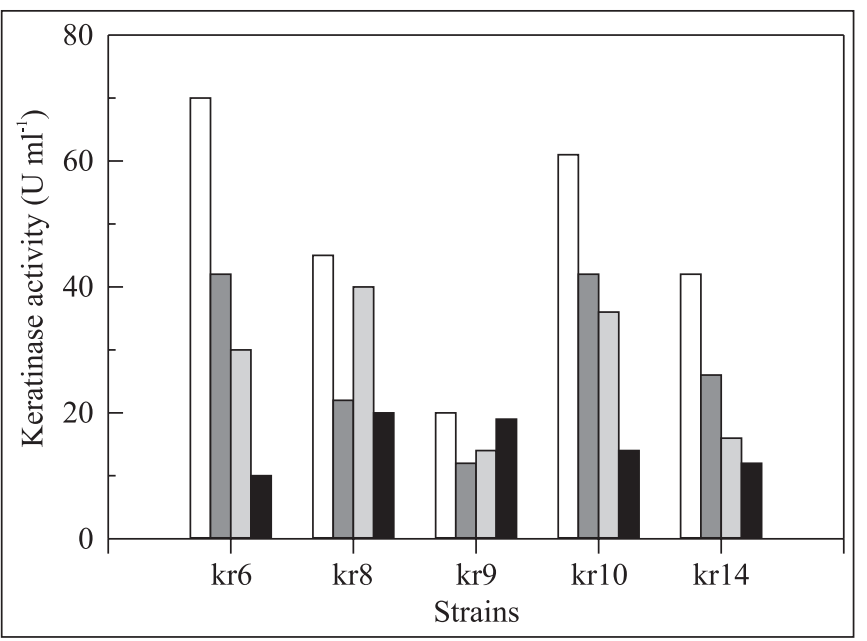

Figure 2. Keratinase activity during growth of keratinolytic bacteria on keratin wastes. Activity was measured after growth for $48 \mathrm{~h}$ at $30^{\circ} \mathrm{C}$ in medium containing $10 \mathrm{~g} \mathrm{l}^{-1}$ of either raw feathers (white bars), powdered chicken nails (dashed bars), bovine hair (gray bars), or wool (black bars).

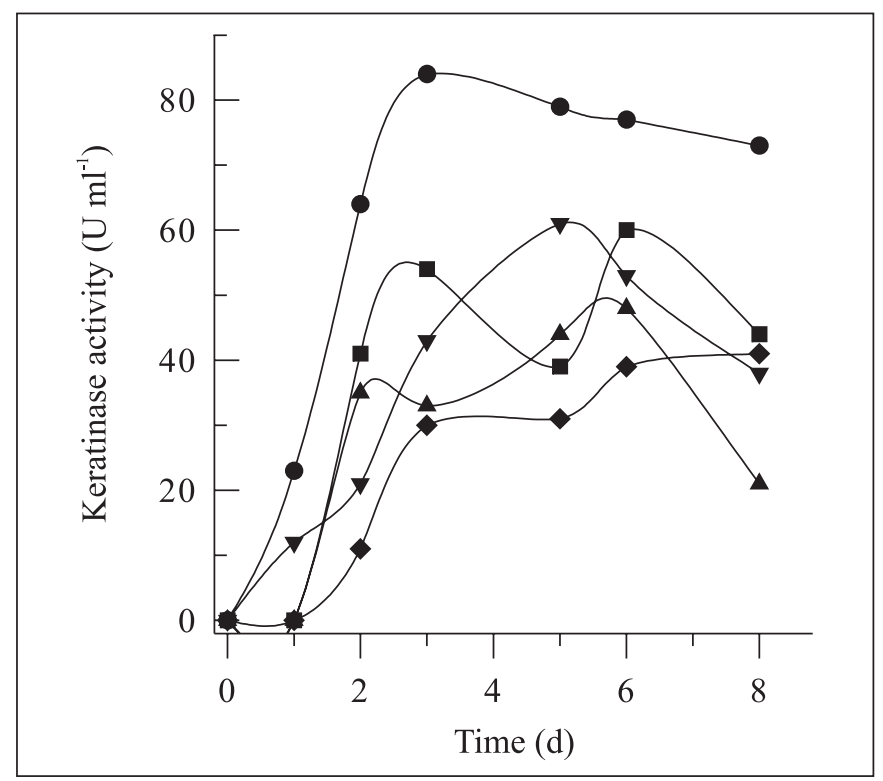

Figure 3. Keratinase activity during growth of keratinolytic bacteria in feather meal broth. Enzyme activities were measured using azokeratin as substrate. Each point represents the mean of three independent experiments. ( $) \mathrm{kr} 6,(\mathbf{\square}) \mathrm{kr} 9,(\boldsymbol{\Delta}) \mathrm{kr} 14$, $(\nabla) \mathrm{kr} 10,(\bullet) \mathrm{kr} 8$. 
The proteolytic activities of keratinolytic strains were compared with commercial enzymes by determining the hydrolysis of azokeratin and azocasein. Keratinase produced by strain kr10 exhibited higher specific activity degrading azocasein and azokeratin when compared to other enzymes (Table 2). The enzyme preparations were similar in hydrolysis of keratin substrate compared with commercially available microbial peptidases such as pronase, derived from Streptomyces griseus, and alcalase, form B. licheniformis.

\section{DISCUSSION}

Bacteria were isolated from a poultry processing plant, that owned keratinolytic activity and ability to degrade keratin wastes. These bacteria present different characteristics, such as a broad temperature range of growth. The optimal proteolytic activities were detected between 30 and $37^{\circ} \mathrm{C}$, whereas previously described keratinolytic bacteria mostly have feather-degrading activity at elevated temperatures $(1,6,17)$. However, these strains behave similar to a Vibrio strain $\mathrm{kr} 2$, previously isolated from decomposing feathers (24). An optimum keratin-degrading activity at mesophilic temperatures should be a desirable characteristic because these microorganisms may achieve hydrolysis with reduced energy input.

Preliminary identification tests indicate that strains kr8, kr9 and kr14 belong to the Proteobacteria or CytophagaFlavobacterium group, and that strain $\mathrm{kr} 10$ is an actinomycetes. In agreement with this data, Lucas et al. (15) noted that featherdegrading Gram-negative bacteria isolated from soils belonged to the Proteobacteria or Cytophaga-Flavobacterium group. The most studied keratinolytic bacteria are Bacillus spp., which have been described to possess feather-degrading activity $(9,14)$. Bacillus licheniformis is a well known keratinolytic organism, possessing the gene kerA, which has been cloned and sequenced (13). However, data on Gram-negative bacteria are relatively scarce and feather-degrading activity has been described only recently for Vibrio sp. (24), Chryseobacterium sp. (23) and Xanthomonas sp. (4).

An increase in $\mathrm{pH}$ values was observed during feather degradation, a trend similar to other microorganisms with large keratinolytic activities $(8,24)$. This trend may be associated with proteolytic activity, consequent deamination reactions and the release of excess nitrogen as ammonium ions. The increase in $\mathrm{pH}$ during cultivation is pointed as an important indication of the keratinolytic potential of microorganisms (8).

Microorganisms growing on medium containing feather meal as a unique carbon and nitrogen source presented variable activity on azokeratin, suggesting that this enzyme may be inductive. Substrate levels in the medium may regulate enzyme secretion. Strain kr6 showed to be more adapted to keratinase production using keratin as substrate, since the maximum keratinase activity of the isolate was observed during early growth, and the strain displayed a higher total activity during incubation. The azokeratin/azocasein hydrolysis ratio was higher for strains kr6 and kr14, suggesting preferred utilization of keratin as substrate.

Through the strategy of isolation of keratinolytic microorganisms utilized in this work, bacteria presenting high keratinolytic activity were selected. Considering that feather protein has been showed to be an excellent source of metabolizable protein (10), and that microbial keratinases enhance the digestibility of feather keratin $(12,20)$, these keratinolytic strains could be used to produce animal feed protein. In addition, the selected isolates were able to grow and display keratinolytic activity in diverse keratin wastes. This would be beneficial for the utilization of these residues. These novel isolates present potential biotechnological use in processes involving keratin hydrolysis.

Table 2. Hydrolysis of azoproteins with peptidases. ${ }^{a}$

\begin{tabular}{lccc}
\hline \multicolumn{1}{c}{ Enzyme } & $\begin{array}{c}\text { Activity on azocasein } \\
\text { (U/mg protein) }\end{array}$ & $\begin{array}{c}\text { Activity on azokeratin } \\
\text { (U/mg protein) }\end{array}$ & $\begin{array}{c}\text { Keratin: } \\
\text { casein ratio }\end{array}$ \\
\hline Culture supernatant of kr6 & 19.2 & 6.1 & 0.32 \\
Culture supernatant of kr8 & 10.7 & 3.0 & 0.28 \\
Culture supernatant of kr9 & 14.6 & 3.5 & 0.24 \\
Culture supernatant of kr10 & 48.4 & 9.1 & 0.19 \\
Culture supernatant of kr14 & 15.8 & 4.8 & 0.30 \\
Trypsin & 18.6 & 3.1 & 0.17 \\
Papain & 23.1 & 2.7 & 0.12 \\
Pronase & 34.1 & 10.5 & 0.30 \\
Alcalase & 29.3 & 6.9 & 0.24 \\
\hline
\end{tabular}

${ }^{a}$ Commercial enzymes were dissolved at $1 \mathrm{mg} \mathrm{mL}^{-1}$ in $50 \mathrm{mM}$ tris, $\mathrm{pH} 8.0$, and then assayed for azoproteins as described in Materials and Methods. 


\section{ACKNOWLEDGEMENTS}

This work was supported by CNPq and FAPERGS (Brazil).

\section{RESUMO}

\section{Bactérias queratinolíticas isoladas de resíduos de penas}

O objetivo deste estudo foi caracterizar bactérias queratinolíticas isoladas resíduos de penas. Quatro isolados foram selecionados após crescimento em meio sólido contendo farinha de pena como única fonte de carbono e nitrogênio e avaliados quanto a atividade proteolítica em placas de ágar leite. Foram identificadas três linhagens Gram-negativas (pertencentes aos gêneros Burkholderia, Chryseobacterium e Pseudomonas) e uma Gram-positiva (Microbacterium sp.). Estas bactérias cresceram em vários resíduos queratinosos como farinha de pena, penas de frango, unhas de frango, pelos e lã. A atividade queratinolítica foi observada durante crescimento, mas a degradação completa dos substratos não foi observada em todos os casos. O caráter proteolítico das enzimas foi determinado usando azoqueratina e azocaseína como substratos. As queratinases foram ativas em ambos substratos e apresentaram hidrólise de queratina comparável a peptidases microbianas disponíveis comercialmente. Estes novos isolados queratinolíticos apresentam potencial uso biotecnológico em processos relacionados com hidrólise de queratina.

Palavras-chave: pena, queratina, peptidase, proteólise

\section{REFERENCES}

1. Atalo, K.; Gashe, B.A. Protease production by a thermophilic Bacillus species (P-001A) which degrades various kinds of fibrous proteins. Biotechnol. Lett., 15, 1151-1156, 1993.

2. Böckle, B.; Galunski, B.; Müller, R. Characterization of a keratinolytic serine protease from Streptomyces pactum DSM40530. Appl. Environ. Microbiol., 61, 3705-3710, 1995.

3. Bradbury, J.H. The structure and chemistry of keratin fibers. Adv. Prot. Chem., 27, 111-211, 1973.

4. De Toni, C.H.; Richter, M.F.; Chagas, J.R.; Henriques, J.A.; Termignoni, C. Purification and characterization of an alkaline serine endopeptidase from a feather-degrading Xanthomonas maltophilia strain. Can. J. Microbiol., 48, 342-348, 2002.

5. Elmayergi, H.H.; Smith, R.E. Influence of growth of Streptomyces fradiae on pepsin- $\mathrm{HCl}$ digestibility and methionine content of feather meal. Can. J. Microbiol., 17, 1067-1072, 1971.

6. Friedrich, A.B.; Antranikian, G. Keratin degradation by Fervidobacterium pennavorans, a novel termophilic anaerobic species of the order Thermotogales. Appl. Environ. Microbiol., 62, 2875-2882.

7. Holtz, J.D. Bergey's Manual of Determinative Bacteriology. Williams \& Wilkins, Baltimore, 1997, 787p.

8. Kaul, S.; Sumbali, G. Keratinolysis by poultry farm soil fungi. Mycopathologia, 139, 137-140, 1997.

9. Kim, J.M.; Lim, W.J.; Suh, H.J. Feather-degrading Bacillus species from poultry waste. Process Biochem., 37, 287-291, 2001.
10. Klemersrud, M.J.; Klopfenstein, T.J.; Lewis, A.J. Complementary responses between feather meal and poultry by-product meal with or without rumminally protected methionine and lysine in growing calves. J. Anim. Sci., 76, 1970-1975, 1998.

11. Kushwaha, R.K.S. The in vitro degradation of peacock feathers by some fungi. Mykosen, 26, 324-326, 1983.

12. Lee, C.G.; Ferket, P.R.; Shih, J.C.H. Improvement of feather digestibility by bacterial keratinase as a feed additive. FASEB J., 59, 1312, 1991.

13. Lin, X.; Kelemen, D.W.; Miller, E.S.; Shih, J.C.H. Nucleotide sequence and expression of $\operatorname{ker} \mathrm{A}$, the gene encoding a keratinolytic protease of Bacillus licheniformis PWD-1. Appl. Environ. Microbiol., 61, 1469-1474, 1995.

14. Lin, X.; Inglis, G.; Yanke, L.; Cheng, K.J. Selection and characterization of feather-degrading bacteria from canola meal compost. J. Ind. Microbiol. Biotechnol., 23, 149-153, 1999.

15. Lucas, F.S.; Broennimann, O.; Febbraro, I.; Heeb, P. High diversity among feather-degrading bacteria from a dry meadow soil. Microb. Ecol., 45, 282-290, 2003

16. MacFaddin, J.F. Biochemical tests for identification of medical bacteria. Lippincott, Williams \& Wilkins, Baltimore, 2000, 912p.

17. Mohamedin, A.H. Isolation, identification and some cultural conditions of a protease-producing thermophilic Streptomyces strain grown on chicken feather as substrate. Int. Biodeter. Biodegrad., 43 , 13-21, 1999.

18. Moritz, J.S.; Latshaw, J.D. Indicators of nutritional value of hydrolyzed feather meal. Poultry Sci., 80, 79-86, 2001.

19. Nam, G.W.; Lee, D.W.; Lee, H.S.; Lee, N.J.; Kim, B.C.; Choe, E.A.; Hwang, J.K.; Suhartono, M.T.; Pyun, Y.R. Native feather degradation by Fervidobacterium islandicum AW-1 a new isolated keratinaseproducing thermophilic anaerobe. Arch. Microbiol., 178, 538-547, 2002.

20. Odetallah, N.H.; Wang, J.J.; Garlich, J.D.; Shih, J.C.H. Keratinase in starter diets improves growth of broiler chicks. Poultry Sci., 82, 664-670, 2003.

21. Onifade, A.A.; Al-Sane, N.A.; Al-Musallan, A.A.; Al-Zarban, S. Potentials for biotechnological applications of keratin-degrading microorganisms and their enzymes for nutritional improvement of feathers and other keratins as livestock feed resources. Bioresour Technol., 66, 1-11, 1998.

22. Parry, D.A.T.; North, A.C.T. Hard a-keratin intermediate filament chains: substructure of the $\mathrm{N}$ - and $\mathrm{C}$-terminal domains and the predicted structure and function of the C-terminal domains of type I and type II chains. J. Struct. Biol., 122, 67-75, 1998.

23. Riffel, A.; Lucas, F.; Heeb, P.; Brandelli, A. Characterization of a new keratinolytic bacterium that completely degrades native feather. Arch. Microbiol., 179, 258-265, 2003.

24. Sangali, S.; Brandelli, A. Feather keratin hydrolysis by a Vibrio sp. kr2 strain. J. Appl. Microbiol., 89, 735-743, 2000.

25. Santos, R.M.D.; Firmino, A.A.P.; Sá, C.M.; Felix, C.R. Keratinolytic activity of Aspergillus fumigatus Fresenius. Curr. Microbiol., 33 , 364-370, 1996.

26. Wang, X.; Parsons, C.M. Effect of processing systems on protein quality of feather meal and hog hair meal. Poultry Sci., 76, 491-496, 1997.

27. Williams, C.M.; Richter, C.S.; MacKenzie, J.M.; Shih, J.C.H. Isolation, identification, and characterization of a feather-degrading bacterium. Appl. Environ. Microbiol., 56, 1509-1515, 1990.

28. Williams, C.M.; Lee, C.G.; Garlich, J.D.; Shih, J.C.H. Evaluation of a bacterial feather fermentation product, feather-lysate, as a feed protein. Poultry Sci., 70, 85-94, 1991.

29. Young, R.A.; Smith, R.E. Degradation of feather keratin by culture filtrates of Streptomyces fradiae. Can. J. Microbiol., 21, 583-586, 1975. 